\title{
Coronal decompensation of the trunk by means of a set of show lifts Coronal decompensation of the trunk by means of a set of shoe lifts
}

\author{
Michele Romano*, Deborah Luzzi, Alessandra Negrini, Stefano Negrini \\ From 10th International Conference on Conservative Management of Spinal Deformities - SOSORT 2013 \\ Annual Meeting \\ Chicago, IL, USA. 8-11 May 2013
}

\section{Background}

A shoe lift (SL) is often used in the treatment of scoliosis curves in two main cases: (1) an identified discrepancy of the legs' lengths in order to obtain a better balance of the pelvis or (2) a recognized improvement of some specific outcome, like the hump magnitude, when the SL is adopted.

\section{Purpose}

The purpose of this study is to measure the trunk pattern in response to the use of a SL (for this study, a series of SLs). In case of a pre-existing coronal decompensation, we observed the trunk reaction when the SL is respectively under the short leg.

\section{Methods}

We evaluated 27 consecutive patients (26 females and 1 male) who visited our Institute for spine diseases (scoliosis or hyperkyphosis). With the patient in a standing position, we performed a set of tests with a 3-dimensional rastereography (DIERS Formetric 4D) with different SL (5mm, $10 \mathrm{~mm}$ and $15 \mathrm{~mm}$ ) placed alternatively under each foot. We assessed the variations of two important elements: the change of pelvic inclination and the change of the line that joins $\mathrm{C} 7$ and the middle of the sacral spine (C7-MSS). For simplicity, we divided the entire group of patients into two subgroups. One subgroup of patients (13) showed (in standing and normal position) a physiological inclination of the line between $\mathrm{C} 7$ and the center of the sacrum towards the right (average $7.08 \mathrm{~mm} \pm 6.79$ ). The other subgroup of patients (15) showed a physiological inclination

\footnotetext{
* Correspondence: michele.romano@isico.it
} ISICO, Milan, Italy

(c) 2013 Romano et al.; licensee BioMed Central Ltd. This is an Open Access article distributed under the terms of the Creative Commons Attribution License (http://creativecommons.org/licenses/by/2.0), which permits unrestricted use, distribution, and reproduction in any medium, provided the original work is properly cited. of the line between $\mathrm{C} 7$ and the center of the sacrum towards the left (average $-12.13 \mathrm{~mm} \pm 8.58$ ).

\section{Results}

We found that the use of the SL was not efficient for the improvement of C7-MSS. When the patients showed a physiological inclination of the spine towards the left, we expected a progressive improvement of this inclination if the patients used a SL under the left foot, and a relative worsening if the patients used a SL under the right foot. The situation was the same if the patients had a physiological inclination of this line towards the right. The results show a completely different pattern. Tables 1 and 2 below show the mean inclinations of this line, using the three SL:

\section{Table 1}

\begin{tabular}{|c|c|c|c|c|c|}
\hline \multicolumn{6}{|c|}{ Physiological inclination of the spine towards the right ( 13 patients) } \\
\hline \multicolumn{6}{|c|}{ S.L.under the right foot and relative inclinations } \\
\hline S.L. $5 \mathrm{~mm}$ & $6.62 \pm 6.5$ & S.L. $10 \mathrm{~mm}$ & $6.77 \pm 11.12$ & S.L. $15 \mathrm{~mm}$ & $7.38 \pm 8.18$ \\
\hline \multicolumn{6}{|c|}{$\begin{array}{l}\text { S.L. under the left foot and relative inclinations } \\
\text {. }\end{array}$} \\
\hline S.L. $5 \mathrm{~mm}$ & $6.92 \pm 9.05$ & S.L. $10 \mathrm{~mm}$ & $8,54 \pm 9.29$ & S.L. $15 \mathrm{~mm}$ & $5.92 \pm 7.19$ \\
\hline
\end{tabular}

\section{Table 2}

\begin{tabular}{|c|c|c|c|c|c|}
\hline \multirow{2}{*}{\multicolumn{6}{|c|}{$\begin{array}{l}\text { Physiological inclination of the spine towards the } \\
\text { S.L. under the left foot and relative inclinations }\end{array}$}} \\
\hline & & & & & \\
\hline $\begin{array}{l}\text { S.L. } \\
5 \mathrm{~mm}\end{array}$ & $\begin{array}{l}-11.27 \\
\pm 10.91\end{array}$ & $\begin{array}{l}\text { S.L. } \\
10 \mathrm{~mm}\end{array}$ & $\begin{array}{l}-13.07 \\
\pm 11.49\end{array}$ & $\begin{array}{l}\text { S.L. } \\
15 \mathrm{~mm}\end{array}$ & $\begin{array}{l}-13.00 \\
\pm 17.30\end{array}$ \\
\hline \multicolumn{6}{|c|}{ S.L. under the right foot and relative inclinations } \\
\hline $\begin{array}{l}\text { S.L. } \\
5 \mathrm{~mm}\end{array}$ & $\begin{array}{l}-10.40 \\
\pm 8.43\end{array}$ & $\begin{array}{l}\text { S.L. } \\
10 \mathrm{~mm}\end{array}$ & $\begin{array}{l}-10.80 \\
\pm 8.24\end{array}$ & $\begin{array}{l}\text { S.L. } \\
15 \mathrm{~mm}\end{array}$ & $\begin{array}{l}-9.47 \\
\pm 14.68\end{array}$ \\
\hline
\end{tabular}




\section{Conclusions and discussion}

The use of a SL $(5 \mathrm{~mm}, 10 \mathrm{~mm}$ and $15 \mathrm{~mm})$ positioned under each foot did not change the pattern of the inclination (theoretically, a reduction or an increase of the inclination of C7-MSS) measured in standing and normal positions. The spine seems to have an individual anti-gravity pattern that cannot be modified by the use of a SL.

Published: 18 September 2013

doi:10.1186/1748-7161-8-S2-O30

Cite this article as: Romano et al:: Coronal decompensation of the trunk

by means of a set of show lifts Coronal decompensation of the trunk

by means of a set of shoe lifts. Scoliosis 2013 8(Suppl 2):O30.

Submit your next manuscript to BioMed Central and take full advantage of:

- Convenient online submission

- Thorough peer review

- No space constraints or color figure charges

- Immediate publication on acceptance

- Inclusion in PubMed, CAS, Scopus and Google Scholar

- Research which is freely available for redistribution

Submit your manuscript at www.biomedcentral.com/submit 